Creech, A., \& Hallam, S. (2011). Learning a musical instrument: The influence of interpersonal interaction on outcomes for schoolaged pupils. Psychology of Music, 39(1), 102-122.

\title{
Learning a musical instrument: the influence of interpersonal interaction on outcomes for school-aged pupils
}

Word count: 8815 inclusive of references and tables (6269 excluding references and tables).

\section{Introduction}

Accounts of pupil-parent-teacher relationships within the specific context of instrumental learning suggest that human interaction has the power to shape our teaching and learning experience (Davidson \& Borthwick, 2002; Easton, 1989; Menuhin, 1977; Weschler-Vered, 1986). The potential for the development of close interpersonal relationships is often realised within the music teaching studio, where it is not unusual for pupils to learn with the same teacher for a number of years and with high levels of support from parents (Creech, 2006).

'It is natural and common for teachers and pupils to come to feel affection (a desire for another's welfare and happiness as an individual) for each other, because long contact tends in itself to breed it, because they often go through painful struggles together (which again tends to foster it) and (in the case of small children) because the situation tends to be like a mother-child situation and to call forth in the parties something resembling natural maternal or filial affection ...'

(Downie, Loufoot, \& Telfer, 1974, p. 160)

The aim of this paper is to explore the implications for pupils of interpersonal interaction with their teachers and parents within the context of learning a musical instrument. The research reported here differs from previous studies in that its explicit aim is to represent pupils' attitudes towards interpersonal interaction within learning 
Creech, A., \& Hallam, S. (2011). Learning a musical instrument: The influence of interpersonal interaction on outcomes for schoolaged pupils. Psychology of Music, 39(1), 102-122.

partnerships. The extent to which these pupil attitudes relating to interpersonal interaction may play a key role in shaping learning experience will be explored. Specifically, this paper addresses the question of whether facets of interpersonal interaction (conceptualized here as relating to control or responsiveness) within pupilteacher and pupil-parent dyads account for significant variability in the pupils' learning outcomes.

\section{Background}

In instrumental tuition, pupil-teacher relationships have been found to be a cornerstone of effective teaching and crucial in determining the level of musical expertise which the individual is able to attain (Howe \& Sloboda, 1991; Sosniak, 1990; Manturzewska, 1990). Furthermore, there is a large body of evidence that parent-pupil relationships are also key in helping the child to follow a domain-specific (musical) path (Creech, 2008). Student personality characteristics have been found to determine the way that teacher behaviours are perceived (Schmidt, 1989b; Schmidt \& Stephans, 1991). Gustafson (1986) suggests that there may also be tacit interpersonal dynamics operating between teachers and pupils, whereby defence mechanisms may be adopted by teachers to ward off unpleasant memories relating to their own experiences as learners. Inevitably, some teacher-pupil-parent matches will be better than others, thus significantly influencing outcomes for pupils (Hallam, 2006).

An overview of the literature relating to pupil-teacher-parent relationships in instrumental learning encompasses prominent themes of shared purpose, pupil-teacher rapport and parental support. Furthermore, in the wider field of educational and parenting research, the importance of representing pupils' voices has been 
Creech, A., \& Hallam, S. (2011). Learning a musical instrument: The influence of interpersonal interaction on outcomes for schoolaged pupils. Psychology of Music, 39(1), 102-122.

highlighted, as has the importance of maintaining a balance of control and responsiveness within pupil-parent-teacher partnerships.

Shared purpose: Close agreement amongst pupils, their parents and teachers with respect to learning objectives has been found to be a feature of successful learning partnerships. Duke (1999) found that a mutual sense of purpose amongst highly effective piano teachers and their pupils was positively associated with pupils who considered their piano study to be successful. Similarly, children's feelings of satisfaction in relation to their music lessons were explored by Rife, Shnek, Lauby, \& Lapidus (2001), who reported that highly satisfied instrumental pupils were motivated by the challenges set by teachers as well as by encouragement from parents. Likewise, Jorgensen (1998) found that a high level of agreement on expectations and preferences in instrumental teaching was negatively related to the intensity of conflict but positively related to cooperation amongst the teachers and students. Interpersonal communication research suggests that human values, expressed by Jorgensen as expectations and preferences, are fundamental and stable. The degree of differences that may be tolerated before value differences become an obstacle to effective group functioning has been investigated (Tubbs, 1984). Jorgensen employed the term zone of tolerance to describe the margin within which a certain amount of incompatibility in expectations and preferences within the instructional context may be borne (Jorgensen, 1998).

Pupil-teacher rapport: Rapport within pupil-teacher relationships has been found to influence pupils' musical development. In the context of the music classroom Lamont 
Creech, A., \& Hallam, S. (2011). Learning a musical instrument: The influence of interpersonal interaction on outcomes for schoolaged pupils. Psychology of Music, 39(1), 102-122.

(2002, p. 56) found that the degree to which pupils liked their music teachers influenced the development of positive musical identities, 'an important step on the way to becoming a more sophisticated musician'. Personality characteristics of instrumental teachers in one-to-one lessons, including extraversion-introversion and sensing-intuition, have been found to account for differences in the extent of positive feedback offered to students; Schmidt (1989a) reported that relatively extravert and intuitive teachers were found to offer more positive feedback. The nature of the teacher-student relationship has been found to be a possible source of stress for music instructors (Heston, Dedrick, Raschke, \& Whitehead, 1996) and a possible source of psychological stress for instrumental students (Persson, 1995). Persson's cohort of conservatory level music students desired a personal, mentoring relationship with their performance teachers. 'The sense of being brought up by a 'musical parent' rather than by some informal performance expert was very important to a majority of the participating students' (Persson, 1995, p. 10). These findings contrast with those of Davidson, Howe, \& Sloboda (1995), whose younger pupil respondents (still in the care of their parents) indicated that as they progressed and matured they valued musical expertise in their teachers more than warmth or responsiveness. The research reported in this paper investigates this apparent contradiction and in particular explores the extent to which responsiveness or control within pupil-teacher and pupilparent dyads may influence outcomes for pupils.

Parental support: In addition to the possible ramifications of interpersonal processes between pupil and teacher, personal, behavioural and cognitive support offered to children by parents has been found to be a key factor in sustaining a child's musical 
Creech, A., \& Hallam, S. (2011). Learning a musical instrument: The influence of interpersonal interaction on outcomes for schoolaged pupils. Psychology of Music, 39(1), 102-122.

well-being (Creech, 2006; Pruett, 2003). Zdzinski (1996) reported that parental involvement was positively related to cognitive, affective and performance outcomes for pupils and that pupils at all grade levels could benefit from parental involvement.

Powerful images of musicians' parents have been immortalized in accounts of the lives of many iconic figures in Western music. Parents have been depicted as exerting an enormous influence on their children's musical development, as in the cases of Mozart (Solomon, 1994), Clara Schumann (Galloway, 2002), and more recently, Yehudi Menuhin (Menuhin, 1977) and Jacqueline du Pré (Easton, 1989), to name but a few. Furthermore, earlier empirical studies (Brokaw, 1982; Davidson, Howe, Moore, \& Sloboda, 1996; Doan, 1973; Sloboda \& Howe, 1992; Sosniak, 1985) have demonstrated that it is not unusual for parents to involve themselves integrally in the process of their children's instrumental learning, one possible consequence being the development of complex relationships amongst parent, teacher and pupil.

Pupils' voices in educative partnerships: In recent years educational researchers have concerned themselves with the dynamics of parent-teacher-pupil interactions, as they relate to effective teaching. MacGilchrist (1997, p. 48) concluded that a fundamental and essential element of effective teaching was '...interactive communication linked to the relationship with the learners'. MacGilchrist emphasized the importance of the capacity for participants to work co-operatively, allowing the feelings of teacher, pupil and parent to be respected. Noddings (1988) put forth the view that there was more to teaching than domain-specific attainment. According to this view, a characteristic of excellent teaching is a teacher-student 
Creech, A., \& Hallam, S. (2011). Learning a musical instrument: The influence of interpersonal interaction on outcomes for schoolaged pupils. Psychology of Music, 39(1), 102-122.

relationship where the student is treated 'with respect and consideration' and where the teacher models 'desirable' patterns of interaction, using 'teaching moments as caring occasions' (Noddings, 1988, p. 223).

The interactive nature of educative partnerships was emphasized by Johnson (1991) who contended that to treat parents as consumers on behalf of their children is to devalue children, treating them as the private property of parents, with no individual preferences. Her view that students need to be included in negotiations between family and school was supported by Brown, Mounts, Lamborn, \& Steinberg (1993) who suggested children in all age groups, including secondary school students, welcome interaction between themselves, their parents and their teachers, and that parental influence on children's behaviour remains extensive in adolescence. Crozier (1999) emphasized the need for pupils to have some control over parents' involvement, highlighting the importance of negotiation rather than imposition of psychological control characterized by intrusive or manipulative controlling/surveillance measures (Baumrind, 2005; Crozier, 1999). Crozier here touched on the issue, so stark in adolescence, of the delicate balance between dimensions of agency (the drive for independence) and communion (the need to be engaged with others), which has been identified both in the literature relating to parenting style (Baumrind, 1989; Brown et al., 1993; Noack, 1998) and that concerned with interpersonal style (Van Tartwijk et al., 1998) and relationships (Birtchnell, 1993; Noller, Feeney, \& Peterson et al.; 2001, Tubbs, 1984). Researchers and theorists have argued that 'people function most cohesively and confidently in contexts in which they experience significant others as being both caring and autonomy-supportive' (Noack, 1998, p. 227), and achieving a successful balance in 
Creech, A., \& Hallam, S. (2011). Learning a musical instrument: The influence of interpersonal interaction on outcomes for schoolaged pupils. Psychology of Music, 39(1), 102-122.

this respect may be a key factor in providing personal support for children's musical development (Creech, 2006).

Schultz Jorgensen (2004) argued that a child's inner learning environment, comprising mind, thoughts and knowledge, is shaped by social relationships and the degree to which he or she is able to exercise influence within the outer learning environment. In this vein he proposed a model of pupil influence within the learning partnership, entitled the 'ladder of participation'. A range of levels of pupil influence were represented, with the most passive pupil voice being portrayed at the stage where 'adults take all the decisions and children are informed', while at the opposite end of the ladder the most active pupil voice was portrayed as the stage where 'children make decisions and adults are only involved if children ask for help' (Schultz Jorgensen, 2004, pp. 119-120). Schultz Jorgensen suggested that if the aim of education in any domain is to engage pupils fully then they must be given an active voice; from this stance there need not be any contradiction between the notion of democracy within teacher-pupil relationships and the attainment of positive learning outcomes.

Control and responsiveness: Repeatedly, the findings of research concerned with how best to sustain appropriate and effective pupil-parent and pupil-teacher interaction place emphasis on the importance of the interpersonal dimensions of responsiveness and control. In this vein, interactive processes amongst parents and professionals engaged in the provision of early childhood education were investigated by Henry (1996), who proposed a model of effective parent-professional-child interaction, with the potential to meet basic human needs for trust, autonomy and 
Creech, A., \& Hallam, S. (2011). Learning a musical instrument: The influence of interpersonal interaction on outcomes for schoolaged pupils. Psychology of Music, 39(1), 102-122.

control for all participants dependent upon a balance of responsiveness, control and involvement.

Van Tartwijk (1998) presented a model of effective teaching based on the concepts of control and responsiveness. This is similar to conceptions of a successful authoritative parenting style encompassing both parental responsiveness and demandingness (Baumrind, 1989; Maccoby \& Martin, 1983). Steinberg, Elmen, \& Mounts (1989) elucidated the notion of authoritative parenting, claiming that authoritative parents, whose parenting style was found to contribute to academic aspirations and achievement amongst their children, treated their children warmly and democratically, yet with a degree of behavioural control. Dimensions of these teaching and parenting models were captured in Birtchnell's interpersonal theory (Birtchnell, 1993). Representing the control construct as an upperness-lowerness axis and the responsiveness construct as a closeness-distance axis, Birtchnell made the point that healthy interpersonal interactions may occur at any point on this matrix. While upperness provides the opportunity to impart knowledge and exert influence, lowerness provides a space where individuals may receive care and attention and benefit from other's knowledge. While closeness represents the possibility for communion, distance provides opportunities for development of agency.

In summary, the literature suggests that pupils flourish in the context of democratic relationships with both their parents and their teachers. Furthermore, pupils seek support from parents throughout their educational careers, within a framework of the freedom to develop agency and yet to maintain communion. In the domain of music there is some evidence that pupils value close, responsive relationships with their teachers, as well as expertise. There is also evidence that as 
Creech, A., \& Hallam, S. (2011). Learning a musical instrument: The influence of interpersonal interaction on outcomes for schoolaged pupils. Psychology of Music, 39(1), 102-122.

pupils develop they may seek different types of support within both the pupil-parent dyad and pupil-teacher dyad.

Despite their evident importance as constructs within the fields of parenting, interpersonal relating and effective teaching, previous research in the domain of instrumental learning has neither specifically examined the interpersonal dimensions of responsiveness and control within learning partnerships, nor explored how these dimensions might influence learning experience. The research presented here explores pupils' attitudes relating to how responsiveness and control are manifest within their relationships with their teachers and parents, in the context of learning a musical instrument. Secondly, this research investigates the extent to which responsiveness and control influence specific facets of learning experience, which were conceptualized as pupil outcomes that had been defined in earlier research (Creech, 2001) and include enjoyment of music, satisfaction with lessons, motivation, self-efficacy, self-esteem and pupil attainment.

\section{Methods}

\section{Development of the Survey}

The views of pupils were elicited via the 'Survey of Pupil Attitudes', developed from existing research instruments that measure a) children's satisfaction with instrumental lessons (Rife, Shnek, Lauby, \& Lapidus, 2001) and b) interpersonal qualities of teachers (Wubbels, Creton, \& Levy, 1993).

For the research reported here, material from the two sources noted above was adapted in order to provide an insight into the influence of interpersonal dynamics on outcomes for pupils. The new version was piloted with a group of 30 pupils and 
Creech, A., \& Hallam, S. (2011). Learning a musical instrument: The influence of interpersonal interaction on outcomes for schoolaged pupils. Psychology of Music, 39(1), 102-122.

scrutinized by experts. Items were discarded where 1) they did not bear significant correlations with the overall scale to which they belonged;2) respondents indicated they did not understand the statement and 3) the experts did not agree that the statement was an indicator of the overall scale to which it belonged.

The aim of the survey was to establish a measurement of how the interpersonal dimensions of control and responsiveness influenced outcomes for pupils that had been defined in earlier research (Creech, 2001). Hence in addition to groups of statements relating to scales for interpersonal mechanisms conceptualized as control and responsiveness, the survey included scales for outcomes that were defined as enjoyment of music, satisfaction with lessons, motivation, self-efficacy and self-esteem.

Wubbels, Creton, \& Levy's (1993) Questionnaire on Teacher Interaction (QTI) provided a model of interpersonal behaviour developed from Leary (1957), who conceptualized all interpersonal behaviour around the two axes of responsiveness and control. The original QTI, which included a scale for self-efficacy, was developed and tested for reliability by Dutch and Australian researchers (Brekelmans, 1989; Creton \& Wubbels, 1984; Fisher, Fraser, \& Wubbels, 1992; Wubbels, Creton, Brekelmans, \& Hooymayers, 1987). Alpha coefficients on each scale (segment of the model) were consistently greater than .70, demonstrating internal consistency. Based on Wubbels et al.'s (1993) model of interpersonal behaviour as being represented around the two axes of responsiveness and control, the survey of pupils developed for this research included 5 point Likert scales ranging from strongly disagree to strongly agree that measured these interpersonal dimensions as they were manifested within pupil-teacher and pupil-parent dyads. 
Creech, A., \& Hallam, S. (2011). Learning a musical instrument: The influence of interpersonal interaction on outcomes for schoolaged pupils. Psychology of Music, 39(1), 102-122.

Basing their research on the premise that children's feelings of satisfaction are vital to learning because they provide the motivation necessary to persevere, Rife, Shnek, Lauby, \& Lapidus (2001) examined factors related to satisfaction with private music lessons from a child's perspective. To this end they developed a measure of music lesson satisfaction. Internal consistency of the Music Lesson Satisfaction Scale (MLSS), which included questions regarding likes and dislikes about lessons, teachers, musical styles and repertoire, practice, intrinsic and extrinsic motivators and family influence, was high (Cronbach's Alpha =.94). The MLSS was adapted for the research reported here in order to create measures of pupil self-efficacy, self-esteem, enjoyment, motivation and satisfaction.

Musical attainment levels were measured by the UK National Qualifications Framework level $(0=$ beginner; $1=$ Associated Board of the Royal Schools of Music $(\mathrm{ABRSM})$ grade $1-3 ; 2=\mathrm{ABRSM}$ grade $4-5 ; 3=\mathrm{ABRSM}$ grade $6-8 ; 4=$ post ABRSM grade 8), assessed in each case by the teacher.

\section{Sample}

Three hundred and thirty-seven violin pupils were surveyed, representing a response rate of $42 \%$. 251 were female and 76 were male (10 did not report their gender). Questionnaires were distributed to ten pupils each by eighty violin teachers in the UK who were all members of the European String Teachers' Association, the Incorporated Society of Musicians, or the British Suzuki Institute. The teachers were given clear instructions to include pupils falling within the age 6-18 bracket and were asked to be non-selective in all other respects. The questionnaires were completed by pupils in their own time and returned in freepost envelopes. The age range of 
Creech, A., \& Hallam, S. (2011). Learning a musical instrument: The influence of interpersonal interaction on outcomes for schoolaged pupils. Psychology of Music, 39(1), 102-122.

respondents was $8-18(\mathrm{M}=12)$, and the sample included those who had just begun learning ranging up to those who had been learning for in excess of 6 years. The mean number of years studied was 5 and the average musical attainment level was National Qualifications Framework level 2 (ABRSM grade 4). The pupils had lessons in one-to-one contexts. Sixty percent of pupils learnt by 'no particular method', 19\% learnt by the Suzuki method, and the remainder learnt by a number of other specified teaching methods.

\section{Findings}

\section{Underlying dimensions of control and responsiveness scales}

A principal component (PC) analysis of the control and responsiveness scales was carried out, with the intention of creating an index of any underlying interpersonal dimensions contributing to these constructs. The pupil control and responsiveness scales met the criteria for a valid PC analysis (Field, 2000): 1) in each case a correlation matrix of all of the scale variables confirmed all of the coefficients were smaller than 0.9 and the majority of significance values were less than $0.05,2$ ) for each scale the Bartlett's test of sphericity was significant $(\mathrm{p}<0.05)$ and 3$)$ the KMO measurement of sampling adequacy yielded a value of 0.9 for the responsiveness scale and 0.7 for the control scale. Thus, in accordance with Kaiser (1960) principal component analyses were carried out in order to ascertain whether there were underlying dimensions contributing to these constructs. Component loadings greater than 0.298 for a sample size greater than 300 were considered significant (Stevens, 1992). Eignevalues greater than 1 were retained, and in order to ensure that variables were loaded maximally on to only one component. Varimax rotation was selected. 
Creech, A., \& Hallam, S. (2011). Learning a musical instrument: The influence of interpersonal interaction on outcomes for schoolaged pupils. Psychology of Music, 39(1), 102-122.

\section{Underlying dimensions of control}

Three components with eigenvalues exceeding 1 were extracted, explaining a total of $58.9 \%$ of the variance (Table 1). A consequence of varimax rotation was to equalize the relative importance of these. Before rotation the difference in importance between component 1 (pupil-teacher deference) and component 3 (pupil-parent autonomy) was approximately $16 \%$. This difference was reduced to $1.5 \%$, after rotation.

\section{TABLE 1 HERE}

Pupils who perceived their teachers to be authoritarian over behaviour, practice and achievement were likely to have high scores on component one, labelled as 'pupil-teacher deference' (component 1). These pupils were consumers of teacherled learning goals and lesson content, and were relatively powerless within the pupilteacher relationship.

Component 2, on the other hand, reflected a dimension of independence and pupil power within the teaching studio. Pupils with high scores on this component, labelled 'pupil teacher influence' contributed to setting goals, and perceived that they had the power to effect changes in the teacher's agenda.

Component 3, interpreted as 'pupil-parent autonomy' was concerned with the pupil's desire to be an autonomous learner within the context of the pupil-parent relationship, taking responsibility for home practice and engaging in a pupil-teacher relationship without parental participation. Pupils with high scores on this component took responsibility for their own learning, striving to achieve independence at home 
Creech, A., \& Hallam, S. (2011). Learning a musical instrument: The influence of interpersonal interaction on outcomes for schoolaged pupils. Psychology of Music, 39(1), 102-122.

and to confine their instrumental learning within the boundaries of an autonomous pupil-teacher relationship.

\section{Underlying dimensions of responsiveness}

Principal components analysis revealed three components with eigenvalues exceeding 1. An effect of varimax rotation was to somewhat equalize the relative importance of each component (Table 2). However, this effect was not dramatic and even after rotation the first component (pupil-teacher accord) accounted for more than double the amount of variance explained by the second component (receptiveness to parental support) and three times that explained by component 3 (pupil-teacher reticence).

\section{TABLE 2 HERE}

Component 1 was concerned with pupil-teacher accord, encompassing the qualities of warmth, understanding, patience and mutual respect. Enthusiasm for the subject matter was included in this cluster of variables. All of the pupil-parent responsiveness variables loaded on to the second component which reflected receptiveness on the part of the pupil towards behavioural support and encouragement from parents. The remaining component was interpreted as pupil-teacher reticence. This third component was concerned with psychological distance between pupil and teacher, representing pupils who were reluctant to engage in a personal relationship with the teacher and not enthusiastic about making music together with the teacher (playing duets).

\section{Outcomes for pupils}


Creech, A., \& Hallam, S. (2011). Learning a musical instrument: The influence of interpersonal interaction on outcomes for schoolaged pupils. Psychology of Music, 39(1), 102-122.

Internal reliability on each of the scales for pupil outcomes was found to be moderate - high (see Table 3 ) and significant correlations ( $\mathrm{p}<.001)$ were found between every individual variable and the overall scale to which it belonged. For each participant, overall mean scores for all of the scales $(\min .=1, \max .=5)$ were calculated by adding together scores for the individual items on each scale and dividing the total by the number of items on that scale.

\section{TABLE 3 HERE}

\section{Enjoyment of music}

Pupils did not make a distinction between enjoyment of lessons, enjoyment of the music they played, and having fun playing the violin (Table 3). The mean response for each variable was over 4 and relatively low standard deviations ranged between .69 and .78 , indicating that pupils generally greatly enjoyed their music making. This positive result was echoed in an overall rating of enjoyment of learning the violin, where the mean response was 7.73 out of a maximum of 10 .

\section{Satisfaction with violin lessons}

There was strong mean agreement that pupils were happy that their parents wanted them to take music lessons $(M=4.25)$ and similarly strong agreement that the best part of lessons was playing their instrument $(\underline{M}=4.25)$. However, there was a lower mean score $(\underline{\mathrm{M}}=3.82)$ in relation to whether pupils liked violin lessons because they learnt more every time and in relation to whether they liked the pieces their teacher gave them $(\underline{M}=3.99)($ Table 3). Furthermore, it is notable that the standard deviations 
Creech, A., \& Hallam, S. (2011). Learning a musical instrument: The influence of interpersonal interaction on outcomes for schoolaged pupils. Psychology of Music, 39(1), 102-122.

for each of these variables were slightly higher than for those relating to the enjoyment scale, ranging from .82 to .89 , suggesting less uniformity in responses. These findings would suggest that enjoyment of playing did not necessarily equate with satisfaction with the content and scope of the lessons themselves.

\section{Motivation}

There was an apparent distinction made between attitudes towards practising and attitudes towards the desire to improve on the instrument (Table 3). Whereas there was strong agreement amongst pupils that they liked it when they improved on their instrument $(\underline{\mathrm{M}}=4.38)$ and that they would like to perfect their playing $(\underline{\mathrm{M}}=4.44)$, there were lower mean scores in relation to statements concerned with whether they liked practising pieces for their violin lessons $(\underline{\mathrm{M}}=3.42)$ and whether it was important to practise scales and exercises $(\underline{\mathrm{M}}=3.68)$. Indeed, standard deviations of .97 and 1.00 (in comparison to standard deviations ranging between .78 and .94 ) indicated that the greatest variability in responses on this scale was in relation to these latter two statements. There was slightly higher agreement that pupils liked practising when it was linked with improving $(\underline{\mathrm{M}}=3.80)$ than when it was linked with preparing for lessons or rehearsing scales and exercises, suggesting that motivation to practise may stem more from a long range goal of improving than from a short term goal of pleasing the teacher or doing well in the next lesson.

\section{Self-efficacy}

Responses to individual variables on the self-efficacy scale suggested that pupils wanted to improve in order to satisfy their own personal goals and, to a lesser extent 
Creech, A., \& Hallam, S. (2011). Learning a musical instrument: The influence of interpersonal interaction on outcomes for schoolaged pupils. Psychology of Music, 39(1), 102-122.

to make their parents happy, more than to fulfil teacher expectations. There was strong agreement amongst pupils $(\underline{\mathrm{M}}=4.19)$ that they liked violin lessons because lessons helped them to improve on the instrument (Table 3, above). In contrast, there was relatively low mean agreement that pupils needed to improve on the instrument in order to satisfy the teacher $(\underline{\mathrm{M}}=2.61)$, but stronger agreement that pupils thought their parents would have liked them to be better players $(\underline{\mathrm{M}}=3.28)$. Although there was a high mean score in relation to whether pupils believed it would make them happier if they were better players $(\underline{\mathrm{M}}=3.78)$, there was a relatively low mean score in relation to the statement 'I don't improve enough on the violin' $(\underline{\mathrm{M}}=2.13)$, suggesting that despite wishing to progress and perceiving that parents wished for them to improve, pupils generally believed that they were sufficiently capable on their instrument. Standard deviations for all but the first variable (noted above) on this scale were above 1.00 , demonstrating that these statements relating to self-efficacy evoked greater variability in responses in comparison with the other outcomes scales.

\section{Self-esteem}

Responses on the self-esteem scale suggested that while perceptions of one's ability to perform well were associated with self-esteem, interaction within the lesson did not always foster this outcome (Table 3, above). While there was strong agreement that they liked it when they played a piece very well $(\underline{M}=4.62)$ and that they felt good about themselves when they improved on the violin $(\underline{\mathrm{M}}=4.34)$ there was a lower mean score and relatively high variation in individual responses in relation to whether pupils liked violin lessons because the lessons made them feel better about themselves $(\underline{\mathrm{M}}=3.41, \mathrm{SD}=.96)$. Furthermore, while they welcomed compliments from their 
Creech, A., \& Hallam, S. (2011). Learning a musical instrument: The influence of interpersonal interaction on outcomes for schoolaged pupils. Psychology of Music, 39(1), 102-122.

friends about their playing $(\underline{\mathrm{M}}=4.22)$, there was less general agreement and the greatest amount of variation in responses regarding whether they liked to play for other people $(\underline{\mathrm{M}}=3.52, \mathrm{SD}=1.2)$.

\section{The influence of control and responsiveness on pupil outcomes}

In order to address the central research question of how pupils' perceptions of interpersonal interaction influenced their learning experience the underlying components for control and responsiveness were examined in relation to each of the pupil outcomes. Standard multiple regressions, using the three control and three responsiveness components as predictors, were carried out in order to examine these items in relation to each of the defined outcomes for pupils. Component scores (calculated by SPSS using the regression method) for each participant on each of the six components, were used to predict each dependent measure, while overall mean scores for each outcome scale were used as the dependent variables.

\section{Enjoyment}

Standard multiple regression revealed that the multiple correlation coefficient for all of the predictors together was $\mathrm{R}=.617$. The model accounted for $38 \%$ of variability in the outcome of pupil enjoyment $\left(\mathrm{F}_{(6,291)}=29.970, \mathrm{p}<.001\right)$. A positive effect was found for pupil-teacher accord (which contributed the most to the model) and receptiveness to parental support, while a negative effect was found for pupil teacher reticence. While the other components were found to be non-significant, two of these (pupil-teacher deference and pupil-teacher influence) yielded probability values close to .05 (Table 4 ). 
Creech, A., \& Hallam, S. (2011). Learning a musical instrument: The influence of interpersonal interaction on outcomes for schoolaged pupils. Psychology of Music, 39(1), 102-122.

\section{TABLE 4 HERE}

\section{Satisfaction with violin lessons}

Positive relationships were found between the outcome of pupil satisfaction and pupil-teacher accord, receptiveness to parental support, and pupil-teacher influence. Receptiveness to parental support was found to make the strongest unique contribution to explaining variance in satisfaction with violin lessons. A negative effect was found for pupil-teacher reticence. The other components were nonsignificant (Table 4, above). The multiple correlation coefficient for all of the predictors together was $\mathrm{R}=.606$ and the model accounted for $37 \%$ of variability in the outcome of satisfaction with violin lessons $\left(\mathrm{F}_{(6,291)}=28.105, \mathrm{p}<.001\right)$.

\section{Motivation}

Receptiveness to parental support (which was found to make the strongest unique contribution to explaining variance in motivation), pupil-teacher accord, and pupilteacher deference were each found to have a positive relationship with the outcome of pupil motivation. Pupil-teacher reticence was found to have a negative relationship with this outcome, while the other components were non-significant (Table 4, above). The multiple correlation coefficient for the model was $\mathrm{R}=.522$ and together the control and responsiveness components accounted for $27 \%$ of the variability in pupil motivation $\left(\mathrm{F}_{(6,291)}=18.148, \mathrm{p}<.001\right)$.

\section{Self-efficacy}

Pupil-teacher deference (making the strongest unique contribution to explaining variance in self-efficacy) and pupil-teacher reticence were each found to have a 
Creech, A., \& Hallam, S. (2011). Learning a musical instrument: The influence of interpersonal interaction on outcomes for schoolaged pupils. Psychology of Music, 39(1), 102-122.

negative effect for pupil self-efficacy, while receptiveness to parental support had a positive effect. The other components were non-significant. The multiple correlation coefficient for the model was $\mathrm{R}=.436$ and all of the predictors together accounted for just $19 \%$ of the variability in pupil self-efficacy $\left(\mathrm{F}_{(6,291)}=11.388, \mathrm{p}<.001\right)$.

\section{Self-esteem}

Receptiveness to parental support was found to be the most important positive predictor of pupil self-esteem, followed by pupil-teacher accord, pupil-teacher deference and pupil-parent autonomy. Pupil-teacher reticence, however, was found to have a negative relationship with this outcome. Pupil-teacher influence was found to be non-significant (Table 4, above). The multiple correlation coefficient for the model was $\mathrm{R}=.626$ and together the predictors accounted for predictors accounted for 39\% of variability in the outcome of pupil self-esteem $\left(\mathrm{F}_{(6,291)}=31.317, \mathrm{p}<.001\right)$.

\section{Musical attainment}

Pupils ranged from beginner to ABRSM post-grade $8(\mathrm{M}=$ grade $4, \mathrm{SD}=2.104)$.

Pupil-teacher influence was found to have a positive relationship with musical grade level while receptiveness to parental support bore a negative coefficient. The other predictors were non-significant (Table 4, above). Together the predictors accounted for $12 \%$ of the variability in pupil attainment, producing a multiple correlation coefficient of $\mathrm{R}=.343\left(\mathrm{~F}_{(6,272)}=6.054, \mathrm{p}<.001\right)$. In order to investigate whether pupil age may have been a mediating influence in this result, the relationship between pupil age and receptiveness to parental support was checked. When pupil ages were banded, significant differences in receptiveness to parental support were found 
Creech, A., \& Hallam, S. (2011). Learning a musical instrument: The influence of interpersonal interaction on outcomes for schoolaged pupils. Psychology of Music, 39(1), 102-122.

between age groups, with pupils aged $8-11$ found to have significantly higher scores for this component than those aged $12-17\left(\mathrm{~F}_{(3,295)}=17.842, \mathrm{p}<.001\right)$. Conversely, in comparison with pupils aged 8-11, pupils aged $15-16$ were found to have significantly higher scores for pupil-teacher influence $\left(\mathrm{F}_{(3,305)}=4.351, \mathrm{p}=.005\right)$.

\section{Discussion}

The findings presented in this paper addressed research questions which asked a) how, in the context of learning a musical instrument, pupils perceive interpersonal dimensions within their relationships with teachers and parents and b) how the dynamics of these interpersonal interactions impact on learning outcomes for violin pupils.

Pupil receptiveness to parental support was found to have a positive relationship with all of the pupil outcomes apart from musical attainment, and in particular made a significant contribution to the outcome of pupil self-esteem. This finding echoes earlier research that has demonstrated that parents of children with high self-esteem and high levels of confidence and competence were genuinely interested in them, concerned for their welfare, attentive to their needs and provided much behavioural, cognitive and personal support (Birtchnell, 1993; Bloom, 1985; Davidson, Howe, Moore, \& Sloboda, 1996; Grolnick, 1997; Kulieke \& OlszewskiKubilius, 1989; Manturzewska, 1990). Furthermore, the conclusion that receptiveness to parental support is associated with positive outcomes for music pupils elucidates the work of O'Neill (2002) who found that children who gave up learning musical instruments were less likely to view their parents as supportive than children who persevered, and that the choice to continue or not was influenced more by the support 
Creech, A., \& Hallam, S. (2011). Learning a musical instrument: The influence of interpersonal interaction on outcomes for schoolaged pupils. Psychology of Music, 39(1), 102-122.

of parents than by the support of teachers. In accordance with a systems perspective, the findings presented here suggest that positive outcomes for pupils are influenced by both the offer of parental support and receptiveness to this support on the part of the child. The negative coefficient found for receptiveness to parental support in relation to musical attainment should be interpreted with caution, as it was shown that the youngest pupils in the beginning stages of playing were those with the highest receptiveness to parental support. It makes intuitive sense that the youngest and least musically advanced pupils in the sample were likely to be those who were the recipients of the greatest amount of behavioural and cognitive support from their parents.

Pupil-teacher accord (responsiveness component) was found to have a positive relationship with pupil enjoyment, satisfaction, motivation and self-esteem. Conversely, for each of these outcomes a negative effect was found for pupil-teacher reticence (which also had a small but statistically significant negative effect for selfefficacy), suggesting that, as with pupil-parent dyads, psychological remoteness within pupil-teacher relationships may in fact have a detrimental effect on learning, while mutual respect, common purpose and the establishment of child-centred rather than teacher-centred goals holds the potential for the achievement of positive outcomes (Hulsebosch, 1991).

The control component defined as pupil-teacher deference was found to have a positive relationship with pupil motivation, self-efficacy and self-esteem. Concurrently the responsiveness component interpreted as pupil-teacher influence was found to have a positive relationship with satisfaction with violin lessons and 
Creech, A., \& Hallam, S. (2011). Learning a musical instrument: The influence of interpersonal interaction on outcomes for schoolaged pupils. Psychology of Music, 39(1), 102-122.

musical attainment. These findings imply that both pupil-teacher deference and influence have their place within effective teacher-pupil relationships, mirroring the control-responsiveness balance that has been shown to be a associated with optimal outcomes within parent-child-professional interactions (Henry, 1996).

There was some evidence that pupil-teacher influence accounted for a small amount of variability in musical attainment. This supports the view that in constructive and productive learning partnerships the pupil benefits from being allowed an active voice (Schultz Jorgensen, 2004). However, it was shown that this effect was perhaps mediated by pupil age, with teenaged pupils perhaps benefiting the most from higher levels of pupil-teacher influence.

The finding that receptiveness to parental support was consistently associated with positive outcomes for pupils (apart from attainment level), while pupil-parent autonomy also produced a positive effect for pupil self-esteem, supports the model of authoritative-reciprocal parenting advocated by Baumrind (1989), whereby a balance of agency (the drive for independence) and communion (the need to be engaged with others) is achieved. Baumrind's model conceptualises a view 'of family functioning in which children are required to be responsive to parental demands and parents accept a reciprocal responsibility to be as responsive as possible to their children's reasonable demands and points of view' (Baumrind, 1989, p. 370). Her contention that 'the success of the parent-child interaction can be assessed by how well the parent balances disciplinary demands with respect for the child and by how well the child balances reliance on parental care with willing progress toward emancipation' (ibid, p. 371) are reflected in the findings presented here. 
Creech, A., \& Hallam, S. (2011). Learning a musical instrument: The influence of interpersonal interaction on outcomes for schoolaged pupils. Psychology of Music, 39(1), 102-122.

In summary, the dynamics of interpersonal interaction with their teachers and parents experienced by pupils learning a musical instrument were shown to potentially account for some variability in learning outcomes. In particular, a balance of 1) control with responsiveness, and 2) agency with communion were found to be associated with positive learning outcomes. There was some evidence that age differences amongst the pupils may have influenced the findings, and further examination of the data, in this respect, will add to an understanding of how instrumental pupils may respond to interpersonal dynamics at various stages of their development.

\section{Conclusion}

The research reported here was limited in the first instance by the possible bias introduced by the method of pupil survey distribution, whereby there was no way of controlling whether teachers were selective when distributing the survey. Nor were there controls for when or where pupils completed the survey, leaving open the possibility that parents or teachers may have influenced the answers provided by pupils. Furthermore, a problem with all survey research is that we do not know how those who did not return the survey may have influenced the results, pointing to the need for future research that accesses different samples. In particular, the fact that this sample did not include any pupils who had discontinued study points to future research that explores whether interpersonal dynamics may be interpreted as predictors of drop-out in instrumental learning. The study reported here was also limited by the fact that it included only violin teachers; future research could investigate whether the findings are instrument-specific. Furthermore, research into 
Creech, A., \& Hallam, S. (2011). Learning a musical instrument: The influence of interpersonal interaction on outcomes for schoolaged pupils. Psychology of Music, 39(1), 102-122.

differences between proponents of various teaching methods would make a valuable contribution to instrumental pedagogy. A further notable limitation relating to the applications of this study was that none of the regression analyses accounted for more than $40 \%$ of the variance in outcomes. This may be related to the relatively low reliability statistics for some of the factors and suggests that there may have been other attitude statements that would more effectively have represented 1) the pupils' attitudes towards the various underlying dimensions of control and responsiveness and 2) their self-reports in relation to the learning outcomes. Finally, this study was concerned with complex social relationships and to interpret its findings as conclusive evidence of causal relationships would be an oversimplification; clearly further research employing qualitative as well as quantitative methodologies are needed.

Notwithstanding the limitations, the results presented here suggest particular ways in which the interpersonal dynamics amongst teachers, pupils and parents impact upon learning outcomes. These findings may serve as a point of reflection for teachers and parents who are concerned with how they might best support children in instrumental learning. Further investigation in the area of interpersonal relationships within the context of instrumental teaching is clearly warranted and has the potential to contribute to positive changes in teaching practice that will benefit pupils, parents and teachers alike. 
Creech, A., \& Hallam, S. (2011). Learning a musical instrument: The influence of interpersonal interaction on outcomes for schoolaged pupils. Psychology of Music, 39(1), 102-122.

\section{References}

Baumrind, D. (1989) 'Rearing Competent Children', in W. Damon (ed.), Child Development Today and Tomorrow, pp.349-378. London: Jossey-Bass.

Baumrind, D. (2005) 'Patterns of Parental Authority and Adolescent Autonomy', New Directions for Child and Adolescent Development 108: 61-69.

Birtchnell, J. (1993) How Humans Relate: A New Interpersonal Theory. UK: Psychology Press.

Bloom, B.S. (Ed.) (1985) Developing Talent in Young People. New York: Ballantine.

Brekelmans, M. (1989) Interpersoonlijk gedrag von docenten in de klas (Interpersonal Teacher Behaviour in the Classroom. Utrecht, The Netherlands: WCC.

Briggs, S. and Cheek, J. (1986) 'The role of factor analysis in the development and evaluation of personality scales', Journal of Personality 54 (1): 106-148.

Brokaw, J.P. (1982) The Extent To Which Parental Supervision And Other Selected Factors Are Related To Achievement Of Musical And Technical-Physical Characteristics By Beginning Instrumental Music Students. Music, University of Michigan, Michigan, USA: Unpublished PHD Dissertation.

Brown, B.B., Mounts, N., Lamborn, S.D. and Steinberg, L. (1993) 'Parenting Practices and Peer Group Affiliation in Adolescence', Child Development 64(2): 467-482.

Creech, A. (2001) Play for me: An exploration into motivations, issues and outcomes related to parental involvement in their children's violin study. Music, University of Sheffield, Sheffield: Unpublished MA dissertation.

Creech, A. (2006) Dynamics, Harmony and Discord: A systems analysis of teacherpupil-parent interaction in instrumental learning. Institute of Education, University of London, London: Unpublished $\mathrm{PhD}$ thesis.

Creech, A. (2008) 'The Role of the Family in Supporting Learning', in S. Hallam (ed.) The Oxford Handbook of Music Psychology, pp. 295-306. Oxford: OUP.

Creton, H. and Wubbels, T. (1984) Discipline problems with beginning teachers. Utrecht, The Netherlands: WCC.

Crozier, G. (1999) 'Parent Involvement: who wants it?', International Studies in Sociology of Education 9(2): 111-130. 
Creech, A., \& Hallam, S. (2011). Learning a musical instrument: The influence of interpersonal interaction on outcomes for schoolaged pupils. Psychology of Music, 39(1), 102-122.

Davidson, J. and Borthwick, S.J. (2002) 'Family Dynamics and Family Scripts: A Case Study of Musical Development', Psychology of Music 30(1): 121-136.

Davidson, J., Howe, M., Moore, D. and Sloboda, J. (1996) 'The role of parental influences in the development of musical performance', British Journal of Developmental Psychology 14(4): 399-412.

Davidson, J., Howe, M. and Sloboda, J. (1995) 'The Role of Parents and Teachers in the Success and Failure of Instrumental Learners', Bulletin of the Council for Research in Music Education 127: 40-44.

Doan, G. (1973) An Investigation of the Relationships Between Parental Involvement and the Performance Ability of Violin Students. Music, Ohio State University, Ohio, USA: Unpublished PHD Dissertation.

Downie, R.S., Loufoot, E.M. and Telfer, E. (1974) Education and Personal Relationships. London: Methuen \& Co Ltd.

Duke, R.A. (1999) 'Measures of instructional effectiveness in music research', Bulletin of the Council for Research in Music Education 143: 1-42.

Easton, C. (1989) Jacqueline du Pré: A Biography. USA: Da Capo Press.

Field, A. (2000) Discovering Statistics Using SPSS. London: Sage.

Fisher, D.L., Fraser, B.J. and Wubbels, T. (1992) Teacher Communication Style and School Environment. ECER Conference, Enshede, The Netherlands.

Galloway, J. (2002) Clara. London: Jonathan Cape.

Grolnick, W. (1997) 'Predictors of Parent Involvement in Children's Schooling', Journal of Educational Psychology 89(3): 538-548.

Gustafson, R. (1986) 'Effects of Interpersonal Dynamics in the Student-Teacher Dyads on Diagnostic and Remedial Content of Four Private Violin Lessons', Psychology of Music 14(2): 130-139.

Hallam, S. (2006) Music Psychology in Education. London: Institute of Education, University of London.

Henry, M. (1996) Young Children, Parents, and Professionals: Enhancing the Links in Early Childhood. London: Routledge.

Heston, M., Dedrick, C., Raschke, D. and Whitehead, J. (1996) 'Job Satisfaction and Stress among Band Directors', Journal of Research in Music Education 44(4): 319-327. 
Creech, A., \& Hallam, S. (2011). Learning a musical instrument: The influence of interpersonal interaction on outcomes for schoolaged pupils. Psychology of Music, 39(1), 102-122.

Hulsebosch, P. (1991) 'Beauty in the eye of the beholder: How and why teachers involve parents', International Journal of Educational Research 15(2): 183200.

Johnson, D. (1991) 'Parents, Students and Teachers: A Three-Way Relationship', International Journal of Educational Research 15(2): 171-181.

Jorgensen, E.R. (1998) 'Modeling Aspects of Type IV Music Instructional Triads', Bulletin of the Council for Research in Music Education 137: 43-56.

Kaiser, H.F. (1960) 'The Application of Electronic Computers to Factor Analysis', Educational and Psychological Measurement 20: 141-151.

Kulieke, M.J. and Olszewski-Kubilius, P. (1989) 'The Influence of Family Values and Climate on the Development of Talent', in J.L.VanTassel-Baska and P. Olszewski-Kubilius (eds.) Patterns of Influence on Gifted Learners, pp.40-59. New York: Teachers College Press.

Lamont, A. (2002) 'Musical Identities and the School Environment', in R.

MacDonald, D. Hargreaves and D. Miell (eds.), Musical Identities, pp.41-59. Oxford, OUP.

Leary, T. (1957) Interpersonal Diagnosis of Personality: A Functional Theory and Methodology for Personality Evaluation. New York: Ronald Press Company.

Maccoby, E. and Martin, J. (1983) 'Socialization in the Context of the Family: ParentChild Interaction'. In E.M. Hetherington and P.H. Mussen (eds.), Handbook of child psychology, Vol. 4. Socialization, Personality and Social Development, pp.1-101. New York: Wiley.

MacGilchrist, B., K., M. and Reed, J. (1997) The Intelligent School. London: Chapman.

Manturzewska, M. (1990) 'A Biographical Study of the Life-Span Development of Professional Musicians', Psychology of Music 18(2): 112-139.

Menuhin, Y. (1977) Unfinished Journey. Great Britain: Macdonald and Jane's Publishers Ltd.

Noack, P. (1998) 'School Achievement and Adolescents' Interactions With Their Fathers, Mothers, and Friends', European Journal of Psychology of Education XIII(4): 503-513.

Noddings, N. (1988) 'An Ethic of Caring and Its Implications for Instructional Arrangements', American Journal of Education 96(2): 215-230. 
Creech, A., \& Hallam, S. (2011). Learning a musical instrument: The influence of interpersonal interaction on outcomes for schoolaged pupils. Psychology of Music, 39(1), 102-122.

Noller, P., Feeney, J.A. and Peterson, C. (2001) Personal Relationships Across the Lifespan. Hove, East Sussex: Psychology Press.

O'Neill, S. (2002) 'Young People and Music Participation Project'. Unit for the Study of Musical Skill and Development, Keele University, www.keele.ac.uk/depts/ps/ESRC/Preportell.doc (Accessed on 11 June 2002).

Persson, R.S. (1995) 'Psychosocial Stressors Among Student Musicians: A Naturalistic Study of the Teacher-Student Relationship', International Journal of Arts Medicine IV(2): 7-13.

Pruett, K. (2003) First patrons: Parenting the Musician, paper presented at 21st Annual Symposium on the Medical Problems of Musicians and Dancers. Aspen, Colorado.

Rife, N.A., Shnek, Z.M., Lauby, J.L. and Lapidus, L.B. (2001) 'Children's Satisfaction with Private Music Lessons', Journal of Research in Music Education 49(1): 21-32.

Schmidt, C.P. (1989a) 'Applied Music Teaching Behaviour as a Function of Selected Personality Variables', Journal of Research in Music Education 37(4): 258271.

Schmidt, C.P. (1989b) 'Individual Differences in Perception of Applied Music Teaching Feedback', Psychology of Music 17(2): 110-112.

Schmidt, C.P. and Stephans, R. (1991) 'Locus of Control and Field Dependence as Factors in Students Evaluations of Applied Music Instruction', Perceptual and Motor Skills 73(1): 131-136.

Schultz Jorgensen, P. (2004) 'Children's Participation in a Democratic Learning Environment', in J. MacBeath and L. Moos (eds.) Democratic Learning, pp.113-131. London: Routledge Falmer.

Sloboda, J. and Howe, M. (1992) 'Transitions in the early musical careers of able young musicians: choosing instruments and teachers', Journal of Research in Music Education 40(4): 283-294.

Solomon, M. (1994) Mozart: A Life. London: Hutchinson.

Sosniak, L.A. (1985) 'Learning to be a Concert Pianist', in B.S. Bloom (ed.) Developing Talent in Young People, pp.19-67. New York: Ballantine.

Steinberg, L., Elmen, J. and Mounts, N. (1989) 'Authoritative parenting, Psychosocial Maturity and Academic Success among Adolescents', Child Development 60(6): 1424-1436. 
Creech, A., \& Hallam, S. (2011). Learning a musical instrument: The influence of interpersonal interaction on outcomes for schoolaged pupils. Psychology of Music, 39(1), 102-122.

Stevens, J.P. (1992) Applied Multivariate Statistics for the Social Sciences (2nd edition). Hillsdale N.J: Erlbaum.

Tubbs, S.L. (1984) A Systems Approach to Small Group Interaction. New York: Random House.

Van Tartwijk, J., Brekelmans, M. and Wubbels, T. (1998) 'Students' Perceptions of Teacher Interpersonal Style: The Front of the Classroom as the Teacher's Stage', Teaching and Teacher Education 14(6): 607-617.

Weschler-Vered, A. (1986) Jascha Heifetz. New York: Schirmer Books.

Wubbels, T., Creton, H., Brekelmans, M. and Hooymayers, H. (1987) 'The Perception of the Teacher-Student Relationship', Tijdschrift voor Onderwijsresearch 12: 3-16.

Wubbels, T., Creton, H. and Levy, J. (1993) 'The Model for Interpersonal Teacher Behaviour', in T. Wubbels and J. Levy (eds.) Do You Know What You Look Like? Interpersonal Relationships in Education, pp.13-28. London: Falmer Press.

Zdzinski, S. (1996) 'Parental Involvement, Selected Student Attributes and Learning Outcomes in Instrumental Music', Journal of Research in Music Education 44(1): 34-48. 
Creech, A., \& Hallam, S. (2011). Learning a musical instrument: The influence of interpersonal interaction on outcomes for schoolaged pupils. Psychology of Music, 39(1), 102-122.

\begin{tabular}{|c|c|c|c|c|c|}
\hline & \multirow[t]{2}{*}{ Mean } & \multirow{2}{*}{$\begin{array}{l}\text { Standard } \\
\text { Deviation }\end{array}$} & 1 & 2 & 3 \\
\hline & & & $\begin{array}{c}\text { Pupil- } \\
\text { teacher } \\
\text { deference } * *\end{array}$ & $\begin{array}{c}\text { Pupil- } \\
\text { teacher } \\
\text { influence } * *\end{array}$ & $\begin{array}{c}\text { Pupil- } \\
\text { parent } \\
\text { autonomy** }\end{array}$ \\
\hline \multicolumn{3}{|l|}{ Eigenvalue, after rotation } & 1.822 & 1.808 & 1.667 \\
\hline \multicolumn{3}{|l|}{ Percentage of variance explained } & 20.3 & 20.1 & 18.5 \\
\hline \multicolumn{3}{|c|}{$\begin{array}{l}\text { Component reliability: } * * * \\
\text { - } \quad \text { Cronbach Alpha } \\
\text { - } \quad(\text { mean inter-item correlation) }\end{array}$} & $\begin{array}{c}.65 \\
(.317)\end{array}$ & $\begin{array}{c}.64 \\
(.367)\end{array}$ & $\begin{array}{c}.55 \\
(.285)\end{array}$ \\
\hline $\begin{array}{l}\text { I like my parent to help me } \\
\text { practise.* }\end{array}$ & 2.99 & 1.31 & & & -.731 \\
\hline $\begin{array}{l}\text { I don't like my parents to sit in on } \\
\text { my violin lesson. }\end{array}$ & 3.04 & 1.41 & & & .771 \\
\hline $\begin{array}{l}\text { I don't like my parents to speak to } \\
\text { my teacher about my progress on } \\
\text { the violin. }\end{array}$ & 2.59 & 1.1 & & & .610 \\
\hline $\begin{array}{l}\text { My teacher accepts my decisions } \\
\text { about how much practice I will do. }\end{array}$ & 3.26 & 1.05 & -.403 & .622 & \\
\hline $\begin{array}{l}\text { My teacher accepts my choices } \\
\text { about which music I want to play. }\end{array}$ & 3.57 & .98 & & .744 & \\
\hline $\begin{array}{l}\text { My teacher accepts my choices } \\
\text { about which musical groups I want } \\
\text { to play in. }\end{array}$ & 3.72 & .95 & & .787 & \\
\hline $\begin{array}{l}\text { My teacher is strict about the } \\
\text { amount of practice I must do.* }\end{array}$ & 2.72 & 1.14 & .789 & & \\
\hline $\begin{array}{l}\text { My teacher is strict about } \\
\text { behaviour during lessons.* }\end{array}$ & 2.71 & 1.12 & .774 & & \\
\hline My teacher has high standards.* & 4.00 & .88 & .637 & & \\
\hline $\begin{array}{l}\text { * Score for this variable was reversed wl } \\
* * \text { Component loadings less than .298 fo } \\
* * * \text { Cronbach Alpha statistic and m } \\
\text { Cheek (1986) recommend reporting } \\
\text { optimal range of .2-.4 is suggested. }\end{array}$ & a calculc & $\begin{array}{l}\text { ing the overa } \\
\text { size greater tl } \\
\text { tem correla } \\
\text { r-item corre }\end{array}$ & $\begin{array}{l}\text { scale } \\
\text { an } 300 \text { are suppr } \\
\text { ions (in bracke } \\
\text { ations for scale }\end{array}$ & $\begin{array}{l}\text { ssed (Stevens, } \\
\text { s) are provid } \\
\text { with less the }\end{array}$ & $\begin{array}{l}\text { 992) } \\
\text { d. Briggs and } \\
10 \text { items. An }\end{array}$ \\
\hline
\end{tabular}

Table 1: Weightings of individual statements in relation to pupil control scale components 
Creech, A., \& Hallam, S. (2011). Learning a musical instrument: The influence of interpersonal interaction on outcomes for schoolaged pupils. Psychology of Music, 39(1), 102-122.

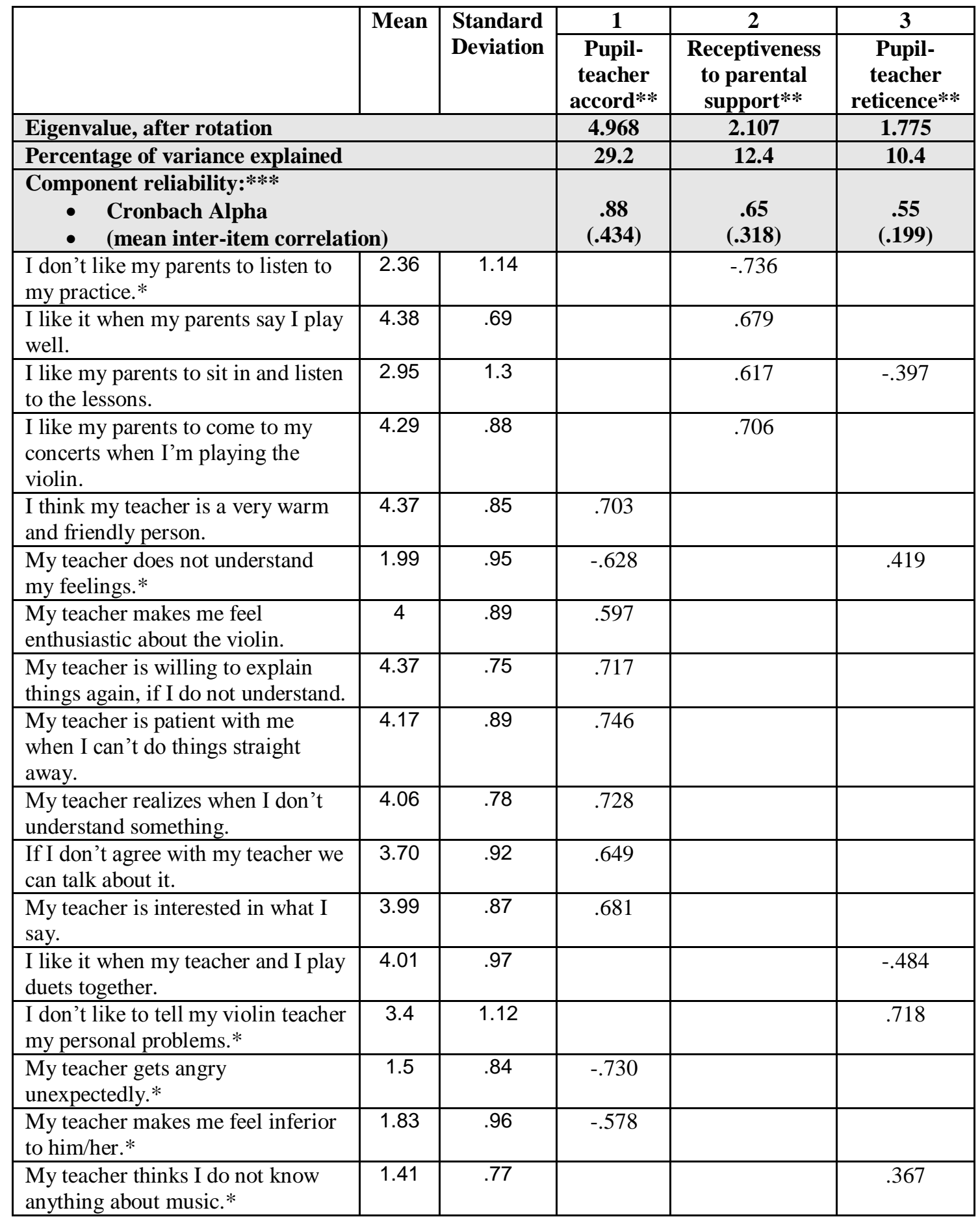

* Score for this variable was reversed when calculating the overall scale

** Component loadings less than .298 for a sample size greater than 300 are suppressed (Stevens, 1992)

${ }^{* * *}$ Cronbach Alpha statistic and mean inter-item correlations (in brackets) are provided. Briggs and Cheek (1986) recommend reporting mean inter-item correlations for scales with less than 10 items. An optimal range of .2-.4 is suggested.

Table 2: Weightings of individual statements in relation to pupil responsiveness scale components 
Creech, A., \& Hallam, S. (2011). Learning a musical instrument: The influence of interpersonal interaction on outcomes for schoolaged pupils. Psychology of Music, 39(1), 102-122.

\begin{tabular}{|c|c|c|c|}
\hline & Mean & SD & Skewness \\
\hline \multicolumn{4}{|c|}{ Pupil enjoyment: Mean inter-item correlation $=.526^{*}$, Cronbach alpha $=.77$} \\
\hline Overall sample score for enjoyment & 4.18 & .615 & .133 \\
\hline I have fun playing the violin. & 4.23 & .78 & .133 \\
\hline I enjoy my violin lessons. & 4.17 & .76 & -1.116 \\
\hline I like the music I play on the violin. & 4.15 & .69 & -.418 \\
\hline \multicolumn{4}{|c|}{ Pupil satisfaction with lessons: Mean inter-item correlation $=.322 *$, Cronbach alpha $=.66$} \\
\hline Overall sample score for satisfaction with lessons & 4.08 & .590 & -.726 \\
\hline $\begin{array}{l}\text { I am happy that my parents want me to take music } \\
\text { lessons. }\end{array}$ & 4.25 & .83 & -1.277 \\
\hline The best part of my lessons is playing my instrument. & 4.25 & .82 & -1.043 \\
\hline I like the pieces my teacher gives me. & 3.99 & .82 & -.708 \\
\hline I like violin lessons because I learn more every time. & 3.82 & .89 & -.477 \\
\hline \multicolumn{4}{|c|}{ Pupil motivation: Mean inter-item correlation $=.182 *$, Cronbach alpha $=.64$} \\
\hline Overall sample score for motivation & 3.65 & .472 & -.352 \\
\hline I would like to perfect my playing on my instrument. & 4.44 & .80 & -1.516 \\
\hline $\begin{array}{l}\text { I like it when I improve because then I can play harder } \\
\text { pieces. }\end{array}$ & 4.38 & .78 & -1.269 \\
\hline I enjoy playing music I already know & 4.00 & .94 & -.772 \\
\hline $\begin{array}{l}\text { I like practising because I know that it helps me to } \\
\text { improve. }\end{array}$ & 3.80 & .86 & -.542 \\
\hline $\begin{array}{l}\text { I think it is important to practise scales and exercises } \\
\text { for my violin lessons. }\end{array}$ & 3.68 & 1.00 & -.473 \\
\hline I like learning new rhythms & 3.53 & .89 & -.429 \\
\hline I like practising pieces for my violin lessons. & 3.42 & .97 & -.459 \\
\hline $\begin{array}{l}\text { The music my teacher gives me is not challenging } \\
\text { enough. }\end{array}$ & 1.97 & .87 & 1.193 \\
\hline \multicolumn{4}{|c|}{ Self-efficacy: Mean inter-item correlation $=.213^{*}$, Cronbach alpha $=.60$} \\
\hline Overall sample score for self-efficacy & 3.27 & .634 & .042 \\
\hline $\begin{array}{l}\text { I like my violin lessons because they help me to get } \\
\text { better at my instrument. }\end{array}$ & 4.19 & .77 & -1.006 \\
\hline It would make me happier if I were a better player.** & 3.78 & 1.02 & .698 \\
\hline My parents would like me to be a better player.** & 3.28 & 1.13 & .164 \\
\hline I need to get better at playing, to satisfy my teacher.** & 2.61 & 1.1 & -.417 \\
\hline I don't improve enough on the violin.** & 2.13 & 1.03 & -.781 \\
\hline \multicolumn{4}{|c|}{ Self-esteem: Mean inter-item correlation $=.388^{*}$, Cronbach alpha $=.72$} \\
\hline Overall sample score for self-esteem & 4.03 & .606 & -.816 \\
\hline I like it when I play a music piece very well. & 4.62 & .6 & -2.013 \\
\hline I feel good about myself when I improve on the violin. & 4.34 & .72 & -1.201 \\
\hline $\begin{array}{l}\text { I like it when my friends compliment me about how I } \\
\text { play. }\end{array}$ & 4.22 & .86 & -1.179 \\
\hline I like to play for other people. & 3.52 & 1.2 & -.485 \\
\hline $\begin{array}{l}\text { I like violin lessons because they make me feel better } \\
\text { about myself. }\end{array}$ & 3.41 & .96 & -.304 \\
\hline
\end{tabular}

* Briggs and Cheek (1986) recommend reporting mean inter-item correlations for scales with less than

10 items. An optimal range of .2-.4 is suggested

** These items were reversed when calculating the overall scale. 
Creech, A., \& Hallam, S. (2011). Learning a musical instrument: The influence of interpersonal interaction on outcomes for schoolaged pupils. Psychology of Music, 39(1), 102-122.

Table 3: Pupil outcomes - means, standard deviations and skewness for enjoyment, satisfaction, motivation, self-efficacy and self-esteem 
Creech, A., \& Hallam, S. (2011). Learning a musical instrument: The influence of interpersonal interaction on outcomes for schoolaged pupils. Psychology of Music, 39(1), 102-122.

\begin{tabular}{|c|c|c|c|c|c|c|c|}
\hline & & \multicolumn{3}{|c|}{ Control Components } & \multicolumn{3}{|c|}{ Responsiveness Components } \\
\hline & & 1 & 2 & 3 & 1 & 2 & 3 \\
\hline $\begin{array}{l}\text { Pupil } \\
\text { outcome }\end{array}$ & & $\begin{array}{c}\text { pupil } \\
\text { teacher } \\
\text { deference }\end{array}$ & $\begin{array}{c}\text { pupil } \\
\text { teacher } \\
\text { influence }\end{array}$ & $\begin{array}{c}\text { pupil } \\
\text { parent } \\
\text { autonomy }\end{array}$ & $\begin{array}{l}\text { pupil } \\
\text { teacher } \\
\text { accord }\end{array}$ & $\begin{array}{l}\text { receptiveness } \\
\text { to parental } \\
\text { support }\end{array}$ & $\begin{array}{c}\text { pupil } \\
\text { teacher } \\
\text { reticence }\end{array}$ \\
\hline \multirow{3}{*}{$\begin{array}{l}\text { Enjoyment } \\
\text { of music }\end{array}$} & Beta & .094 & .109 & .069 & .381 & .287 & -.350 \\
\hline & $\mathrm{t}$ & 1.956 & 1.922 & 1.013 & 6.737 & 4.420 & -6.588 \\
\hline & Sig. & .051 & .056 & .312 & .001 & .001 & .001 \\
\hline \multirow{3}{*}{$\begin{array}{l}\text { Satisfaction } \\
\text { with violin } \\
\text { lessons }\end{array}$} & Beta & .022 & .147 & .084 & .357 & .375 & -.233 \\
\hline & $\mathrm{t}$ & .446 & 2.565 & 1.222 & 6.251 & 5.718 & -4.346 \\
\hline & Sig. & .656 & .011 & .223 & .001 & .001 & .001 \\
\hline \multirow{3}{*}{ Motivation } & Beta & .118 & .097 & -.008 & .261 & .325 & -.204 \\
\hline & $\mathrm{t}$ & 2.261 & 1.572 & -.104 & 4.268 & 4.623 & -3.547 \\
\hline & Sig. & .024 & .117 & .917 & .001 & .001 & .001 \\
\hline \multirow{3}{*}{ Self-efficacy } & Beta & -.232 & .090 & -.049 & .108 & .220 & -.162 \\
\hline & $\mathrm{t}$ & -4.215 & 1.384 & -.622 & 1.677 & 2.965 & -2.678 \\
\hline & Sig. & .001 & .167 & .534 & .095 & .003 & .008 \\
\hline \multirow{3}{*}{ Self-esteem } & Beta & .150 & .052 & .140 & .300 & .569 & -.190 \\
\hline & $\mathrm{t}$ & 3.149 & .926 & 2.066 & 5.354 & 8.862 & -3.608 \\
\hline & Sig. & .002 & .355 & .040 & .001 & .001 & .001 \\
\hline \multirow{3}{*}{$\begin{array}{l}\text { Musical } \\
\text { attainment } \\
\text { (ABRSM } \\
\text { grade) }\end{array}$} & Beta & .011 & .239 & -.076 & -.029 & -.267 & -.090 \\
\hline & $\mathrm{t}$ & .185 & 3.409 & -.897 & -.413 & -3.335 & -1.370 \\
\hline & Sig. & .854 & .001 & .370 & .680 & .001 & .172 \\
\hline
\end{tabular}

Table 4: Standardized Beta coefficients for control and responsiveness components as predictors of pupil outcomes 